\title{
Investigating the Phonological Processes Involved When Yoruba Personal Names Are Anglicized
}

\author{
Eunice Fajobi ${ }^{1} \&$ Bolatito Akomolafe ${ }^{1}$ \\ ${ }^{1}$ Obafemi Awolowo University, Ile-Ife, Nigeria \\ Correspondence: Eunice Fajobi, Obafemi Awolowo University, Ile-Ife, Nigeria. E-mail: eunicefaj@gmail.com
}

Received: Ocotber 30, 2018 Accepted: December 20, 2018 Online Published: January 24, 2019

doi:10.5539/ells.v9n1p24 URL: https://doi.org/10.5539/ells.v9n1p24

\begin{abstract}
Personal names, in African context, are not arbitrary. They are like signposts that convey a wide range of invaluable information about the bearers. Also, they are like a 'social DNA' that discloses the identity, family background, family history, family vocation and family deity of the bearer (Onadipe, 2012). Sadly however, studies, which are mostly sociolinguistic in perspective, abound to show that some of these given personal names are being anglicized among the younger generation of bearers (Soneye, 2008; Faleye \& Adegoju, 2012; Raheem, 2013; Filani \& Melefa, 2014). From the standpoint of socio-phonology and using Knobelauch's (2008) Phonological Awareness as our theoretical framework, this paper investigates the phonological changes that Yoruba personal names undergo when they are anglicized; and their implication for the endangerment of Yoruba language. Perceptual and acoustic analyses of the data sourced from the written and verbalized (as well as recorded) anglicized names of 50 informants from a Nigerian University show "stress-shift" as the major prosodic strategy used by speakers to anglicize Yoruba personal names. Other phonological processes identified include re-syllabification, contraction, elision and substitution; but bearers are not overtly aware of these processes. Findings reveal further that though the "new names" are structurally more English than Yoruba, they are nevertheless pronounced with Yoruba tone by some bearers.
\end{abstract}

Keywords: anglicization, phonological processes, syllabification, Yoruba, tone, stress

\section{Introduction}

Unlike in European countries, personal names in African context are not arbitrary; the prevailing circumstance dictates the name given to a child. In fact, the concept of naming is an integral part of the African culture. Personal names are like signposts as they convey a wide range of information about the bearers. They are signposts that are often tightly knitted with parental or ancestral cultural world view as they reflect the sex, ethnic group, family background, family occupation, family history or family deity of the bearers. The name Fagbenga for instance, reveals the bearer's ethnic group (Yoruba), sex (male), and family deity (Ifa).

According to Faleye and Adegoju (2012), a name is a valuable source of information which can indicate gender, birthplace, nationality, ethnicity, religion and position within a family and the society at large. Dictionary.com (2016) defines a name as a word or a combination of words by which a person, place or thing, a body or class, or any object of thought is designated, called or known. Harder (2008) defines names as 'words signifying special and tangible things, either living, as in the case of a person or an animal, or inanimate, as in the case of a place or a concept.' Harder (2008) further classifies human names into three: personal names (used to distinguish males and females in the human society); first names (given to people at birth) and last name (also known as surname) which reflects an individual's family background, family occupation, location and parentage.

The concept of naming in African context is highly rated because names echo bearers' cultural value. Onadipe (2012) describes a Yoruba name as a 'social DNA' that discloses the identity, family background, family history, family vocation and family deity of the bearer. Raheem (2013) asserts that most Yoruba names are symbolic as they at times portray the bearer's family trade, the family deity or the prevailing circumstance surrounding the child's birth; it conveys meaning to the Yoruba and those who are exposed to the Yoruba culture. In the same vein, Ajileye (2011) submits that Africans ascribe a kind of 'hallowed and mystic aura' to childbirth; hence, naming is seen as a very significant thing. For instance, in Nigeria, a child born with a tangled hair is called "Dàda" but Europeans do not attach special importance to it; rather, they would interpret it scientifically. As a 
matter of fact, the function of a name transcends being a label of linguistic and cultural identity. According to Ogunwale and Bamigbade (2014):

an indigenous African name on the whole personifies the individual; tells some stories about the parents or the family of the bearers, and in a more general sense points to the values of the society in which the individual is born. Africans therefore regard the bearer of a particular name as being potentially able to evince the characteristics contained in the semantic encodings of their names.

A name is like a bridle. The Yoruba people have a proverb that says "Orúko omo ni ijánu omo" that is, a child can be tamed or controlled with his or her name. For instance, one can easily call the attention of an individual in the midst of a crowd with his or her name. Hence, the significance of names cannot be overemphasized.

Typologically, Atolagbe et al. (2015) opine that Yoruba personal names can be classified into four: (1) Oruko Abiso, i.e., names given to a child at birth. These are names that usually mirror the family deity, family vocation, parental wishes and the circumstances surrounding the child's birth as in Ifábiyí, Ọdésolá, Abósèdé (a female child born on Sunday), Ábáyòmí (a child born when all hope of giving birth was lost), Bógundé (suggesting that the child was born during a war), Adéoba or Adéolú (names given to children born into a royal family), etc. (2) Names given due to visible signs on the body of the child, e.g., a male child born with the umbilical cord hanged on his neck is called Òjó and a female child born with the same sign is called Aìná. (3) Names given to children as a result of unusual incidents preceding their birth, e.g., Omópé (a child who exceeds nine months in the womb), Àyòká (a twin who loses his or her second at birth), etc. (4) Names reflecting the unusual behaviours displayed by a child in the first week of his or her birth, e.g., Òní (a child who did not cry immediately after birth) or Olómitútù (a baby who does not like having his or her birth with warm water), etc.

In the present day Yoruba land, however, naming practice has taken a new turn especially among some Yoruba elite. Ogunwale and Bamigbade (2014) report that in Nigeria, a group of Yoruba people were the first to be exposed to the Europeans. Their exposure to western education makes them view anything western as being superior. Hence, they form the habit of dropping their names or replacing part of them, in the name of modernity and religion. Ogunwale and Bamigbade posit, further, that some Yoruba people prefer the English variant of their indigenous names; for instance: "Ayò" is substituted with "Joy", "Àánú" with "Mercy", and so on. Also, circumstantial names are no longer given to children but most times replaced with English names. For instance, a set of twins could be christened "Goodness" and "Mercy" instead of the native "Táíwò" and "Kéhìndé". All these are corroborating evidence for the submission of Oduyoye (2001, cited by Raheem, 2013) that:

...every Yoruba name has a meaning, but the meanings of some of them are getting lost just as many of the names are disappearing with changed social and religious situations, which are the factors that produced the sentiments which the names were meant to commemorate in the first place.

In the same vein and quite unfortunately, some of these given personal names are being anglicized in the name of civilisation, especially among the younger generation of bearers (Soneye, 2008; Faleye \& Adegoju, 2012; Raheem, 2013; Filani \& Melefa, 2014). And when the names are anglicized, they do not bear any phonological or semantic semblance with the original names; resulting in the bastardisation of the Yoruba language and culture. In this study, the researchers investigate the phonological changes that may occur in anglicized Yoruba personal names; and how the changes may impact on the affected Yoruba names as well as on the users' linguistic and cultural values.

\section{Anglicization of Yoruba Personal Names}

\subsection{Anglicization: What and Why}

Anglicization is the adaptation of the linguistic features of English to other languages and cultures. According to Filani and Melefa (2014), anglicization is commonly defined as the use of English expressions or linguistic mannerism in other languages. Also, Soneye (2008) defines anglicization as a form of acculturation whereby there is a linguistic influence of English on other languages. Ajileye (2011) describes it as 'the inclusion of one or more exoglossic lexemes which originate from British or American English into an indigenous word, especially in names.' Following Gorlach (2001), this present study regards as anglicized, any Yoruba personal names that are English in form (i.e., spelling, pronunciation and morphology). By extension, anglicization will be regarded as the adaptation of Yoruba names to English spelling, pronunciation and morphology as in the adaptation of the name Àbáyòmí [abajomi] to Yomex [jomeks] (see Table 4).

People anglicize their names for various reasons. For instance, one of the ways through which Yoruba elite elevate modernism is anglicization. Anglicization of Yoruba personal names is a general phenomenon especially among the Yoruba youths. Filani and Melefa (2014) observe that people anglicize names to present themselves 
as being modern and civilized as Yoruba names appear to them as being too local for the modern world. It is also claimed that anglicized nicknames are brief and sophisticated (Soneye, 2008). Similarly, Ajileye (2011) reports that anglicized names are believed to be modern, brief, compact, snappy, prestigious, elegant, lofty and fashionable. Anglicized nicknames could as well serve as a façade to hide one's true identity. In view of this, Onadipe (2012) notes that individuals with circumstantial names could adopt nicknames to save their faces. For instance, someone who bears "Kílàńkó" (what are we celebrating) could change his or her name to "Killy" in order to conceal the fact that he or she is an Abikú (a child born to die or a reborn dead child). Furthermore, Filani and Melefa (2014) view anglicization as a means of marrying the Yoruba tradition and modernity while Soneye (2008) opines that anglicization of Yoruba personal names has been observed as a means of vocabulary extension and communication of new ideas.

From the foregoing, existing studies on the anglicization of Yoruba personal names seem to have focused more on sociolinguistic description. However, the present researchers are of the view that the anglicized names are unique in the sense that they have dropped their original features and taken up new ones. In terms of pronunciation too, names in this category are subjected to certain processes both at the segmental and suprasegmental levels, which the bearers may or may not be aware of. At the segmental level, for instance, sound segments are modified in various creative ways to de-familiarise the names while at the suprasegmental level, some prosodic changes are made to the names so as to project them with English features. The present researchers are, therefore, interested in investigating the effect of English prosody on Yoruba phonology when Yoruba personal names are anglicized, especially the phonological processes involved for adapting the Yoruba personal names to English structure and pronunciation. To this end, the study will be guided by some research hypotheses thus: (1) When Yoruba personal names are anglicized, the new names are structurally more English than Yoruba; (2) The anglicized names are semantically at par with their original Yoruba names; (3) Anglicization has no implications for the Yoruba language and culture; (4) Despite equating anglicization with modernism and civilization, Yoruba speaking youths are favourably disposed to preserving Yoruba language and culture.

No two languages are known to operate the same phoneme inventory, hence $\$ 2.2$ discusses the English and Yoruba phonemes.

\subsection{English and Yoruba Phoneme Inventory}

Characteristically, English has 20 vowels and 24 consonants while, according to Bamgbose (1969), Yoruba uses 19 classified consonants (as shown in Figure 1) and 12 vowels comprising 7 oral and 5 nasal vowels (Figure 2). That is, Yoruba has lesser phonemes in her inventory than English.

\begin{tabular}{|c|c|c|c|c|c|c|c|c|}
\hline & Bilabial & Labio-dental & Alveolar & Post-Alveolar & Palatal & Velar & Labio-Velar & Glottal \\
\hline Plosives & $\mathrm{b}$ & & $\begin{array}{ll}\mathrm{t} & \mathrm{d}\end{array}$ & & & $\begin{array}{ll}\mathrm{k} & \mathrm{g}\end{array}$ & $\mathrm{kp}$ & \\
\hline Affricates & & & & & ds & & & \\
\hline Fricatives & & $\mathrm{f}$ & $\mathrm{s}$ & $\mathrm{S}$ & & & & $\mathrm{h}$ \\
\hline Nasals & $\mathrm{m}$ & & $\mathrm{n}$ & & $\mathrm{N}$ & & & \\
\hline Lateral & & & 1 & & & & & \\
\hline Approximants & $\mathrm{w}$ & & $\mathrm{r}$ & & $\mathrm{j}$ & & & \\
\hline
\end{tabular}

Figure 1. Yoruba consonant chart

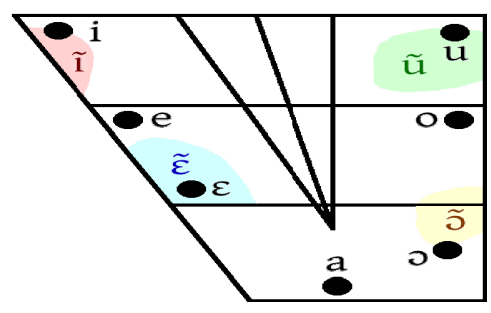

Figure 2. Yoruba vowel chart (Copied from commons.wikimedia.org)

Interestingly however, these languages have phonemes that differ between them just as they have those that are common to them. For instance, while Yoruba does not use diphthongs or show length contrast in vowels like 
English, the latter contains no classified nasal vowels used in the former. Also, the labio-velar plosives (/kp/ and $/ \mathrm{gb} /$ ) of Yoruba are alien to English the same way that the English voiceless palato-alveolar affricate $/ \mathrm{t} /$ and voiced palato-alveolar fricative /3/ are to Yoruba. For our purposes however, and as shown in Tables 2, 3 and 4 below, English and Yoruba sounds that have similar pronunciations will be treated as equivalent sounds. For instance, the vowel sounds $/ \varepsilon /$ and /e/ in the initial syllables of $/ \int \varepsilon s \tilde{a} /$ (Sèsan) and / esi/ (Shessy) respectively are equivalent sounds; hence, $/ \varepsilon /$ in $/ \int \varepsilon s a ̃ /$ is not substituting /e/ in $/ \int \mathrm{esI} /$. The same goes for the Yoruba $/ \mathrm{J} /$ in /dolakpo/ (Dọlápò) and the English /p/ in [dplipi:] (Dollypee). Similarly, the Yoruba /a/ in /abisolala/ (Abísólá) and English $/ \mathfrak{æ} /$ in $/ \mathfrak{r b} /$ (Abby) are treated as equivalents in this study.

\section{Methodology}

\subsection{Theoretical Consideration}

This paper adopts two theories: Knobelauch's (2008) Phonological Awareness (PA) and Kager's (1995) Metrical Theory. On the one hand, Phonological Awareness entails the ability of a child to identify sounds in words. Torgesen and Mathes (1998) term PA as an individual's sensitivity to or consciousness of the phonological structure of words in his/her language; it is concerned with noticing, imagining or manipulating individual sounds in words. Similarly, Yopp and Yopp (2009) define PA as 'sensitivity to the sound structure of language'. Also, Knobelauch (2008) expresses it as the ability of a child to manipulate sounds and words and pun about them. Though our data centres around the youths rather than children, these researchers nevertheless believe that using Knobelauch's (2008) Phonological Awareness theory to analyse our data cannot be counter-productive.

Knobelauch (2008) identifies 11 phonological awareness skills but the only four applicable to this study are:

i. Deletion of syllables (equivalent to contraction)

ii. Deletion of sounds (equivalent to elision)

iii. Addition of sounds (equivalent to epenthesis)

iv. Manipulation of sounds (equivalent to substitution)

On the other hand, the metrical theory is a model that is used to describe stress placement on words (simple or compound), phrases and sentences. According to Kager (1995), the metrical theory emerged as an aspect of nonlinear phonology during the late 70s. The theory was propounded by Liberman in 1975, expounded by Liberman and Prince in 1977 and by Halle and Vergnaud in 1978. The theory is principally concerned with "the hierarchical nature of stress" (Kager, 1995). Faleye (2014) states that this theory employs a binary approach in representing the relationship of prominence that exists between the elements in the metrical grid which is a development on the metrical tree. Unlike the metrical tree, the metrical grid represents the rhythmic structure of a grammatical unit (Kager, 1995) and the primary, secondary and the tertiary stress in a word.

Relating to the above, this study sets to represent the "stress shift" that occasionally occurs in Anglicized Yoruba Personal names (AYPNs) on the metrical grid. As we have observed in this study, for instance, certain AYPNs which have been contracted into two syllables sometimes undergo a regressive stress shift. This is in tandem with the stress rule in English which states that a disyllabic noun should have its stress on the initial syllable; for example: HElen, TAble, BASket, and so on. The notion is illustrated with "Titó (MH)", a Yoruba personal name (YPN) and its anglicized version "Teetoe" thus:

\begin{tabular}{cccc}
\multicolumn{2}{c}{ YPN } & \multicolumn{2}{c}{ AYPN } \\
& $\mathrm{x}$ & $\mathrm{x}$ & \\
$\mathrm{x}$ & $\mathrm{x}$ & $\mathrm{x}$ & $\mathrm{x}$ \\
$\mathrm{x}$ & $\mathrm{x}$ & & \\
$\mathrm{M}$ & $\mathrm{H}$ & $\mathrm{TEE}$ toe \\
$\mathrm{Ti}$ & tó & & $\vee$ \\
& & & (stressed) (unstressed)
\end{tabular}

If one goes by the assumption that speakers use the Yoruba high tone (H) to articulate the English primary stress (Afolayan, 1982; Fajobi, 2013), one can interpret the above as having undergone "stress-shift" in that Tito which is an $\mathrm{MH}$ ( $\mathrm{Mid} \& \mathrm{High})$ tone sequence or sequence of stressed and unstressed syllables has changed in the 
anglicized form to stressed (Tee) and unstressed (toe) syllable sequence; i.e., stress has shifted from the second to the first syllable between the two forms.

\subsection{Procedure for Data Collection}

Basically, the method of investigation employed in this study is that of testing and tape-recording. A structured questionnaire with four sections was administered to the informants. The first section elicited their demographic information. The second section entailed the informants' pronunciation of the original and the anglicized versions of their names which they had written on paper. Their renditions were recorded straight on the speech analyser, PRAAT. The third section comprised questions to elicit information on the informants' attitudinal disposition towards anglicization of names. The fourth section elicited information on their awareness and view about the implications of anglicization for the Yoruba language and culture. The recorded names were subjected to both perceptual and acoustic analysis, the latter using PRAAT. The statistical analysis was based on simple percentile calculations; tables and figures.

\subsection{Subjects}

50 students of the Obafemi Awolowo University (25 males and 25 females), whose ages range between 15 and 31 participated in this study. They were purposively selected because only students whose first language and first name by which they are addressed is Yoruba were eligible to participate. Moreover, the researchers selected only those whose anglicized names have undergone a change in pronunciation and not only in orthographic representation.

\section{Analysis of Data}

Demographically, analysis reveals that $70 \%$ of the 50 informants who participated in this study fall in the age bracket 15 and 25; $28 \%$ are in the age range 26 and 30; while just $2 \%$ fall between ages 31 and above. This shows that majority of them are youths leading to an inference that AYPNs is common only among the youths or that youths are the promoters of anglicization of names.

\subsection{Classification of Test Items According to the Phonological Processes They Have Undergone}

This sub-section analyses the phonological processes the respondents' names have undergone. At a glance, Table 1 shows that all the 50 names analysed in this study have undergone the processes of substitution, contraction, elision and epenthesis. But as revealed further in the table, some names have simultaneously undergone more than one phonological process.

Table 1. Summary of the phonological processes the selected names have undergone

\begin{tabular}{llll}
\hline S/N & Phonological Process & No of names involved & Percentage \\
\hline 1 & Substitution & 9 & 18 \\
2 & Contraction & 10 & 20 \\
3 & Substitution \& Contraction & 22 & 44 \\
4 & Substitution \& Epenthesis & 4 & 8 \\
5 & Elision \& Contraction & 1 & 2 \\
6 & Substitution, Contraction \& Elision & 1 & 2 \\
7 & Substitution, Epenthesis \& Contraction & 3 & 6 \\
& Total & 50 & 100 \\
\hline
\end{tabular}

In other words, in columns 1 and 2 of the table, $18 \%$ and $20 \%$ of the names have undergone substitution and contraction, respectively while columns 3 to 7 present names that have undergone multiple phonological processes. Graphical representation of the findings in Figure 3 shows that the names that have undergone substitution and contraction (simultaneously) have the highest percentage; i.e., $44 \%$ or 22 out of the 50 anglicized names (see columns 3 and 4 of Table 1). 


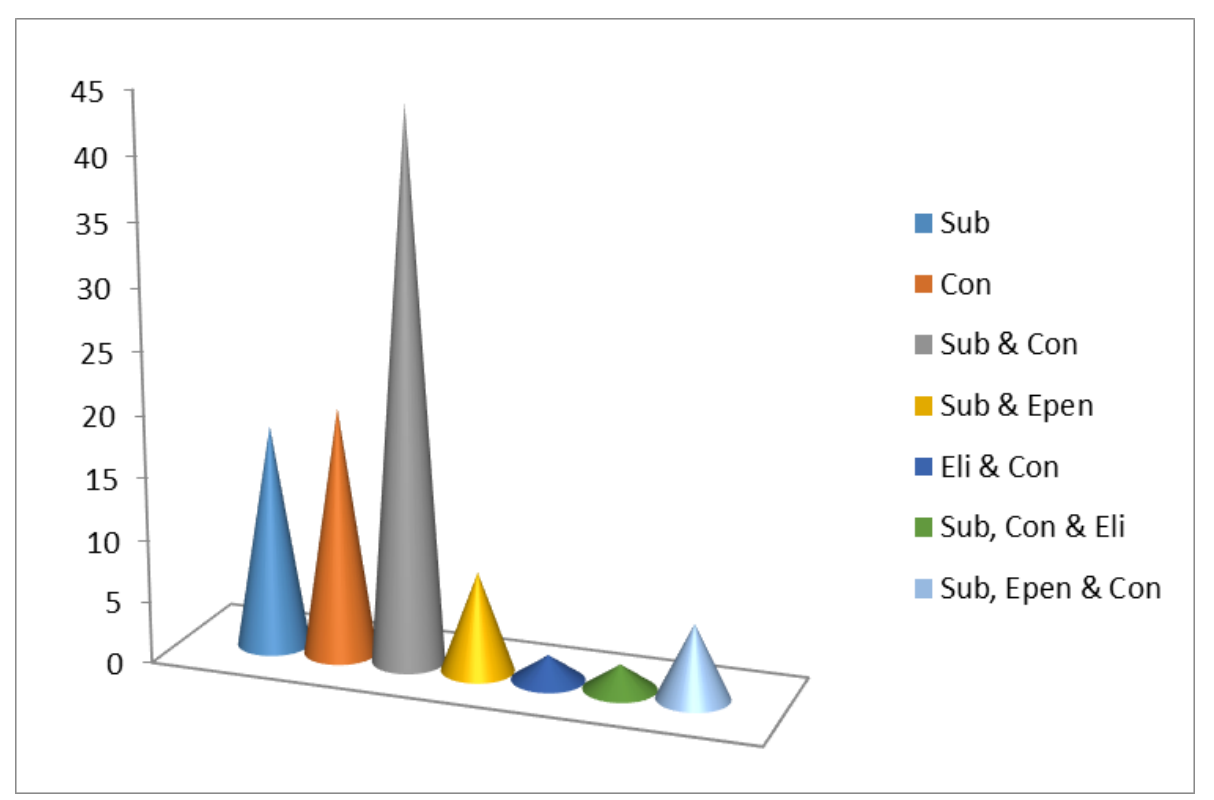

Figure 3. Graphic representation of the phonological processes the names have undergone

\subsection{Phonological Processes in the AYPNs: Further Exposition}

In this sub-section, findings about the phonological processes the anglicized names have undergone to transform from Yoruba to English are itemized; starting with substitution.

\subsubsection{Sustitution, Contraction and Re-syllabification}

Presented in Table 2 are some test items that have undergone sound and/or syllable substitutions that have metamorphosed them into English names. For example, item 2 (Dọlápò-/dolakps/ $\rightarrow$ Dollypee-/dplipi:/) has undergone substitution of the peak of the medial syllable, an unrounded open vowel /a/ with an unrounded half-close front vowel /I/ in the anglicized version. Besides, the rounded open back vowel $/ \mathrm{J} /$ which is the peak of the final syllable in the original name has been substituted with an unrounded close front vowel /i:/ in the anglicized version. Also, item 3 ([femi] - [efem]) has undergone an entire substitution of its syllables; the open syllables /f $/$ / and $/ \mathrm{mi} /$ have not only been replaced with closed syllables /ef/ and /em/ in the anglicized variant, their vocalic elements $/ \varepsilon /$ and $/ \mathrm{I} /$ have also undergone regressive substitution in which the second $(/ \mathrm{I} /)$ is further substituted with /e/. In items 8 (Tee-Y or /ti:waI/) and 9 (Teejay or /ti:dseI/), it seems to the researchers that the pronunciations of the anglicized versions have been informed by their spellings, i.e. their spellings have impacted on their pronunciation, rather than the other way round suggested by Ajileye's (2011) label for the same occurrence (cf. p. 179). The present researchers therefore label the phenomenon "spelling pronunciation".

Table 2. Substitution of sounds and syllables between the informants' original and anglicized names

\begin{tabular}{|c|c|c|c|c|}
\hline $\mathrm{S} / \mathrm{N}$ of Items & Original names & Transcription & Anglicized names & Transcription \\
\hline 1 & Dèjì & [deji] & Deiji & [deIdtI] \\
\hline 2 & Dọlápò & [dolakpo] & Dollypee & [dplıpi:] \\
\hline 3 & Fémi & [femi] & FM & [efem] \\
\hline 4 & Lọlá & [lola] & Lohlar & [ləulæ] \\
\hline 5 & Lọlá & [lola] & Lolly & [loli] \\
\hline 6 & Níkè & [nike] & Nikky & [nikı] \\
\hline 7 & Sèsan & {$\left[\int \varepsilon s a ̃\right]$} & Shessy & {$\left[\int \mathrm{esI}\right]$} \\
\hline 8 & Táyò & [tajo] & Tee-Y & [ti:war] \\
\hline 9 & Túnjí & [tũyi] & Teejay & [ti:dzer] \\
\hline
\end{tabular}

In Table 3, instances of syllable contraction in the anglicized names are apparent. To conform to modernity or sophistication, perhaps, all the anglicized versions of the names presented in the table have fewer syllables compared to those in the original Yoruba names. When /abajomi/ in item 1 changes to /jomi/ for instance, 
syllables $/ \mathrm{a} /$ and $/ \mathrm{ba} /$ are deleted so that the original 4 syllables in $/ \mathrm{a}+\mathrm{ba}+\mathrm{j} 0+\mathrm{mi} /$ are now reduced to only two $/ \mathrm{j} 0+\mathrm{mI} /$. The phenomenon of syllable contraction pervades all the other 9 items represented in the table. For instance, item 2 "Abísólá" is made up of four syllables /a+bi+so+la/ but the anglicized version which is simply $/ æ b \mathrm{~b} /$ has only two syllables, meaning that two syllables have been deleted. By the same token, items $3,4,5,6,7$, 8,9 and 10 have been reduced from 5, 4, 4, 4, 4, 4, 4, 4 syllables to 2, 2, 1, 1, 3, 2, 2 and 2 syllables, respectively.

Table 3. Syllable contraction in the anglicized names

\begin{tabular}{lllllll}
\hline S/N of items & Original name & Transcription & No of Syllables & Anglicised name & Transcription & No of Syllables \\
\hline 1 & Àbáyòmí & [abajomi] & 4 & Yommy & [jomI] & 2 \\
2 & Abíślá & [abisola] & 4 & Abby & [æbI] & 2 \\
3 & Adédàmólá & [adedamola] & 5 & Deydah & [deId ] & 2 \\
4 & Dámilólá & [damilola] & 4 & Dammy & [dæmI] & 2 \\
5 & Moyòadé & [mojoade] & 4 & Moh & [məu] & 1 \\
6 & Olaitan & [olaitã] & 4 & Lhait & {$[$ lart] } & 1 \\
7 & Olúmìdé & [Olúmìdé] & 4 & Olumy & [əulumI] & 3 \\
8 & Tèmítáyò & [temitajo] & 4 & Temmy & [termI] & 2 \\
9 & Ténílá & [tzniola] & 4 & Tenny & [tenI] & 2 \\
10 & Tìmíléhìn & [timilehĩ] & 4 & Timmy & [trmI] & 2 \\
\hline
\end{tabular}

Next, instances of simultaneous substitution and contraction of sounds and syllables between the informant's original and anglicized names in the data are discussed. Items presented in Appendix B have undergone contraction. For instance, item 1 (Abíólá) has been reduced from four syllables /a+bi+o+la/ to two /eI + bi:/. In addition to the contraction process it has undergone, the first syllable (/a/) of the original name (Abiólá) has been substituted with the closing diphthong /eI/ in the anglicized variant. Also, the peak of the second syllable /bi/ which is an unrounded close front vowel /I/ has been replaced with the unrounded half-close front vowel /i:/. The anglicized versions of items 7 (Folly), 13 (Mayor), 21 (Toy) and 8 (-tune - excluding the initial and final sounds - /ai/ and /z/) are homophones of "folly (foolishness)", "Mayor (a male leader in the city)", "toy (a playing object)" and "tune (a song)" respectively in English. This has enhanced the pronunciation of the names.

Another multiple (but simultaneous) phonological processes observed in this study are substitution and epenthesis in the anglicized names. This is exemplified with Tósin (/tosĩ/) and Tosign (/tausain/) where there is substitution of the unrounded close front nasal vowel /ĩ/ in Tósìn with the closing diphthong /aI/ in the anglicized variant (/tousain/). Also, the alveolar nasal $/ \mathrm{n} /$ has been inserted in the anglicized version. This makes the second syllable of the anglicized variant a homophone of "sign (the short form of signature) in English". Similarly, in Wale ((/wale/) to Whalex (/werleks/)) and Wọlé (//wole/ to Wolex (/wDleks/)) (cf. Appendix A), the insertion of the voiceless velar plosive $/ \mathrm{k} /$ and the voiceless alveolar fricative $/ \mathrm{s} /$ in the anglicized variants of /werleks/ and /wDleks/ make them rhyme with the word "Rolex" (a type of wrist watch historically founded in London) which to the bearers is a symbol of prestige.

Findings reveal more interesting details about the anglicization of Tóyòsí (/tojəsi/) as Toyos (/təujDs/) and that of Foláké (/f̧lake/) as Flaky (/flerki/). In the former, there is simultaneous elision and contraction in the anglicized variant. For example, the unrounded close front vowel /I/ in the final syllable of the original name /tojosi/ has been elided in the anglicized version. This has resulted in its contraction from 3 syllables to 2 . In the latter, anglicization of Foláké (/f̧lake/) as Flaky (/flerki/) shows it as having undergone simultaneous processes of substitution, contraction and elision. The name has undergone elision of the peak of its initial syllable $/ \mathrm{J} /$ in the anglicized version ([flerki]). This elision process has resulted in the contraction of the syllables from three $/ \mathrm{fo}+\mathrm{la}+\mathrm{k} \varepsilon /$ to two $/ \mathrm{fle}+\mathrm{kI} /$. In addition to this, the peak of the medial syllable of the original name $/ \mathrm{la} /$ which is an unrounded open vowel $/ \mathrm{a} /$ and the peak of the final syllable $/ \mathrm{k} \varepsilon /$ which is an unrounded half-open front vowel $/ \varepsilon /$ have been substituted with a closing diphthong /eI/ and an unrounded half-close front vowel /I/ in the anglicized version respectively. 
Table 4. Substitution, epenthesis and contraction in the anglicized names

\begin{tabular}{lllllll}
\hline $\mathrm{S} / \mathrm{N}$ of items & Original name & Transcription & No of syllables & Anglicized name & Transcription & No of syllables \\
\hline 1 & Àbáyòmí & [abajomi] & 4 & Yomex & [jDmeks] & 2 \\
2 & Bólúwatifé & [boluwatif $\varepsilon]$ & 5 & Bolex & [bouleks] & 2 \\
3 & Tèmítópé & [temitope] & 4 & Topsy & [topsi] & 2 \\
\hline
\end{tabular}

In item 1, Table 4, the first two syllables in the original version have been elided. This accounts for the reduction in the number of syllables from four $/ \mathrm{a}+\mathrm{ba}+\mathrm{j} \mathrm{j}+\mathrm{mi} /$ to two $/ \mathrm{jDm}+\mathrm{eks} /$ in the anglicized version. Besides, the peak of the final syllable in the original name $(/ \mathrm{mi} /$ ) which is an unrounded close front vowel /i/ (in Yoruba inventory) has been substituted with the unrounded half-open front vowel /e/ in the anglicized version (Yomex). There is also the insertion of the voiceless velar plosive $/ \mathrm{k} /$ and voiceless alveolar fricative $/ \mathrm{s} /$ in the anglicized version of the same item.

\subsubsection{Re-syllabification}

Being Yoruba words, there are no consonant clusters or codas in the original names of the respondents. This is due to the fact that Yoruba phonotactic rule does not permit such. However, the anglicized variants do not conform to Yoruba phonotactic rules. Altogether, out of the 50 names that were analysed, it was discovered that eight of the anglicized names have consonant clusters while 15 (i.e., 30\%) are uttered with codas as in Shegz / egz/, for instance.

As regards re-syllabification, "Bólúwatife" in its original form has the syllable structure CVCVCVCVCV while its anglicized version "Bolex" has the syllable structure CVCVCC (see Appendix A). This reveals further that while the original name conforms to the Yoruba syllable structure which is $(\mathrm{C}) \mathrm{V}$, the anglicized version aligns with the English syllable structural pattern which permits consonant clusters pre- and post-vocalically. In other words, the English variant /bəuleks/ contains two syllables /bəu/ and /leks/. While /bəu/ is CV in structure, /leks/ is CVCC in structure. A further analysis of re-syllabification in the original and anglicized version of "Bólúwatifé" shows that when a Yoruba name is anglicized, the number of syllables may decrease. For instance, while the original name has five syllables CVCVCVCVCV, the anglicized variant /bəuleks/ has only two which are $\mathrm{CV}$ and $\mathrm{CVCC}$ in structure (see Appendix A). Respondents seem to apply the process of re-syllabification in order to give English features to the Yoruba names.

Appendix A reveals the structural classification of the original and anglicized names. Examples of names with consonant clusters as the appendix shows include Àbáyòmí (Yomex), Bólúwatifé (Bolex), Fikémi (Fiks), İtùnú (Itunez), Ségun (Shegz), etc. while those with coda (which does not exist in Yoruba) include /efem/ (VCVC) for Fémi, /lart/ (CVC) for Olaitan and the first syllable in /opzi/ (VC+CV) for Opéyẹmí for instance. Furthermore, it should be noted in names like "Súnkànmí" that the "un" and "an" in Yoruba are not sequences of sounds. Rather, they are nasal vowels represented as [ũ] and [ã] respectively.

\subsubsection{Stress-Shift}

Prosodically, English uses stress (on its syllables) while Yoruba uses tone, but studies (acoustic and perceptual) abound to show that Yoruba-English speakers apply tone rather than stress to the syllables when they speak English (Wells, 1982; Gut \& Milde, 2002; Udofot \& Gussenhoven, 2010; Fajobi, 2013). Similarly, native English speakers have been reported to have the tendency to associate the Yoruba high tone with the English primary stress (Afolayan, 1982). Afolayan carried out an experiment whereby a native speaker of English, alongside other Yoruba-English bilinguals, was asked to identify instances of stress in a recorded Yoruba conversation. Professor Gimson, a native English speaker, was reported to have identified all instances of high tone $(\mathrm{H})$ as having the primary stress. Afolayan then concludes that Professor Gimson's performance depicts that in any environment, the highest pitch i.e., the high tone is connected to the primary stress. It is against this backdrop that stress is analysed between the original and the anglicized versions of the test items, using examples from the data at hand; more so, because these researchers believe that tone and stress constitute the appropriate classificatory prosodic features for analysing the "behaviour of the syllables" in the Yoruba and English names to avoid methodological drawback.

When analysed acoustically, the name Bùsáyò which shows sequences of LHL tones as a Yoruba word reveals the anglicized variant "Bussy" [ ${ }^{1}$ busi] as being pronounced with the first syllable stressed. This means that the "Bu" syllable in the original pronounced with a low tone has now been produced with a "high tone", in Yoruba terms, in the anglicized variant. In other words, that syllable i.e., "Bu" has now been stressed. Stress has now shifted from the second syllable in the original to the first syllable in the anglicized version. 


\section{Bùsáyò $\quad$ Bussy}

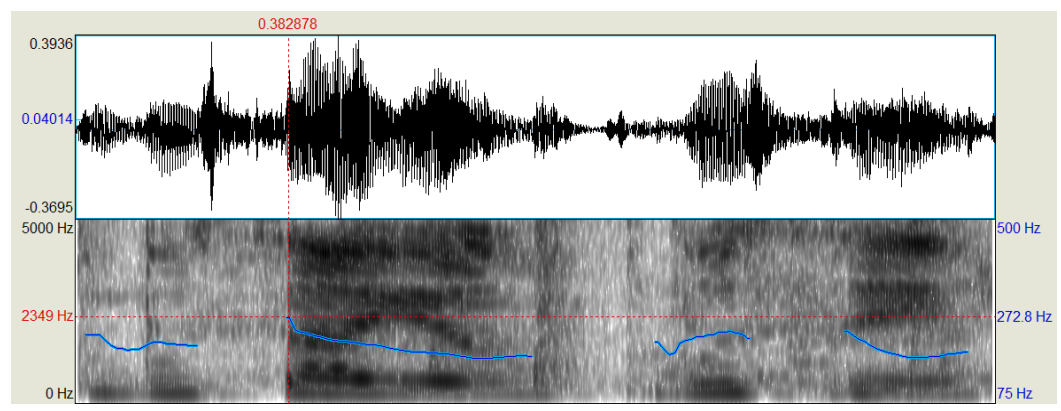

Figure 4a. Respondent 1's rendition of Bùsáyò and Bussy

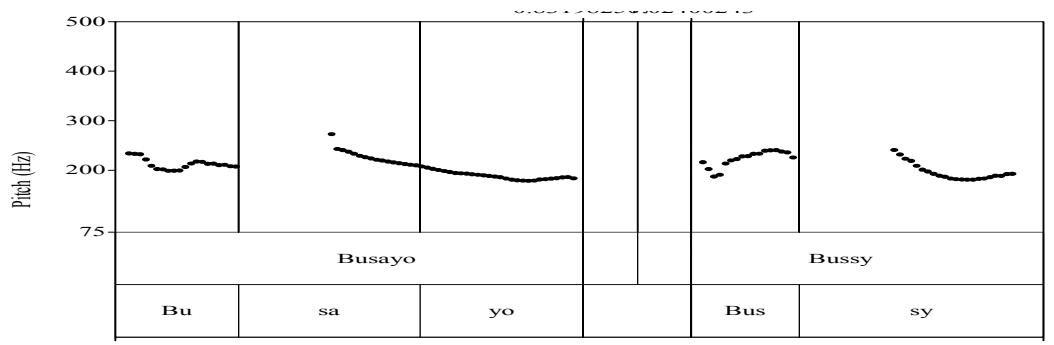

Figure $4 \mathrm{~b}$. Clear pitch trace for Figure $4 \mathrm{a}$

As Figure $4 \mathrm{~b}$ shows, the rise is on syllable "sa" (of Busayo) which is a High tone while the other two tones are lower in pitch. Three syllables LHL are rendered by the informant as $233 \mathrm{~Hz}, 272.8 \mathrm{~Hz}$ and $185.3 \mathrm{~Hz}$ respectively. In the anglicized version, [Bussy (/busi/)] however, the initial syllable /bu/ is said with a mean pitch of $224.06 \mathrm{~Hz}$ while the second syllable /sI/ is said with $195.17 \mathrm{~Hz}$. Therefore, the first syllable is stressed.

To strengthen this point, the name was further analysed using the metrical grid. The grid below shows the metrical analysis.

\section{Original Name}

Bùsáyò

\section{Tone Structure}

LHL

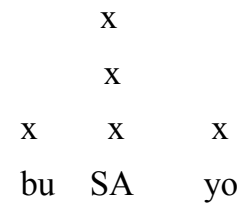

\section{Anglicized version}

Bussy

$\mathrm{x}$

$\mathrm{x}$

BUS

\section{Stress Pattern}

$\left[{ }^{1}\right.$ busi $]$

As the grid reveals, the original version has its prominence on the medial syllable "sa" but prominence has shifted to the initial syllable "Bus" in the anglicized version.

Another name which was discovered to have undergone stress shift is Lọla anglicized as "Lohlar". The tone sequence for "Lọlá" is MH. This means that the High tone is on the second syllable /la/. The anglicized version /ləulæ/, on the other hand, has its primary stress on the initial syllable. Hence, there is a shift of stress from the second syllable "la" /la/ in the original version to the first syllable "Loh" /ləu/ in the anglicized version. To elucidate this fact, the name with its anglicized variant is subjected to metrical and acoustic analyses. 
Original Name

Lọlá
Tone Structure

$\mathrm{MH}$

$\begin{array}{cc} & \mathrm{X} \\ \mathrm{X} & \mathrm{x} \\ \mathrm{x} & \mathrm{x} \\ \mathrm{l} & \mathrm{LA}\end{array}$

A

\section{Anglicized version}

Lohlar
Stress Pattern

$\left[{ }^{1}\right.$ ləulæ $]$
X

$\mathrm{x} \quad \mathrm{x}$

$\mathrm{LOH} \quad$ lar

As presented on the grid above, the final syllable of the original name "la" has the "primary stress" but in the anglicized version, the stress has shifted to the initial syllable "Loh".

\section{Lọlá Lohlar}

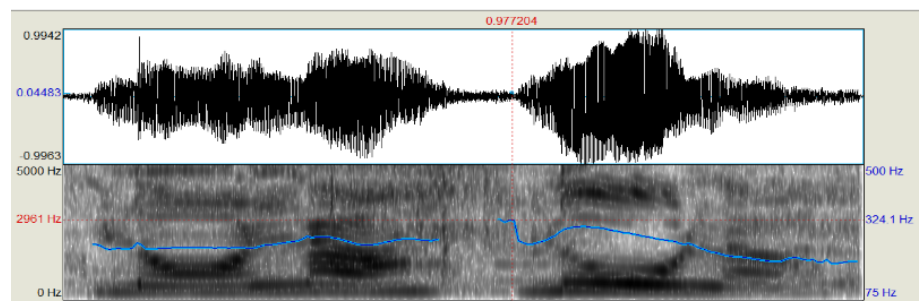

Figure 5a. Respondent 2's rendition of Lọlá and Lohla

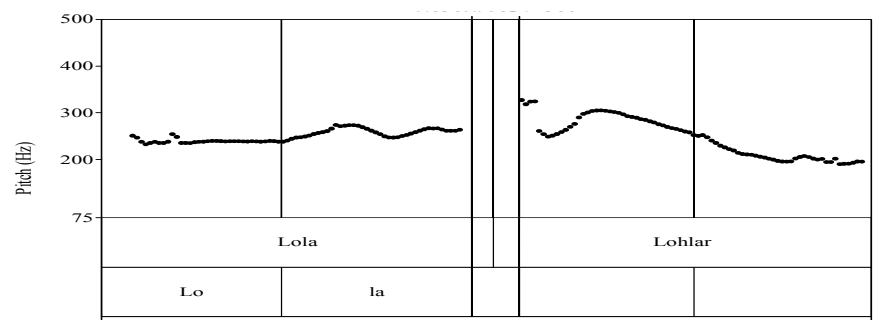

Figure 5b. Clear pitch trace for Figure 5a

As presented in Figure 5b, the pitch of the initial syllable of the original version "Lö" was produced with $244.3 \mathrm{~Hz}$ but it glides up on the second syllable "la" with $246.1 \mathrm{~Hz}$. However, in the anglicized version, the initial syllable "Loh" was produced with the mean pitch of $283.96 \mathrm{~Hz}$ and then glides down to $203.67 \mathrm{~Hz}$ in the second syllable "lar". Therefore, there is a shift of stress from the second syllable in the original version "la" to the first syllable in the anglicized version "Loh".

In what seems to confirm Fajobi's (2013) submission that Nigerian English is spoken with tone rather than stress, findings from the perceptual analysis of our data reveal that majority of the respondents tend to articulate the anglicized names with tones. For instance, "Yomex", which is the anglicized version of "Àbáyòmí" was articulated in what sounds like "Yomekis" (HHL); the more reason the first syllable is easily associated with High tone as can be seen in Figure 6. The pitch traces of "Yomekis" in Figure 6 reveal three clear tones (i.e., HHL) instead of being pronounced with two syllables as an English word or name. 


$$
\text { Yo ([jD]) } \quad \text { me ([me]) } \quad \text { x([kis]) }
$$

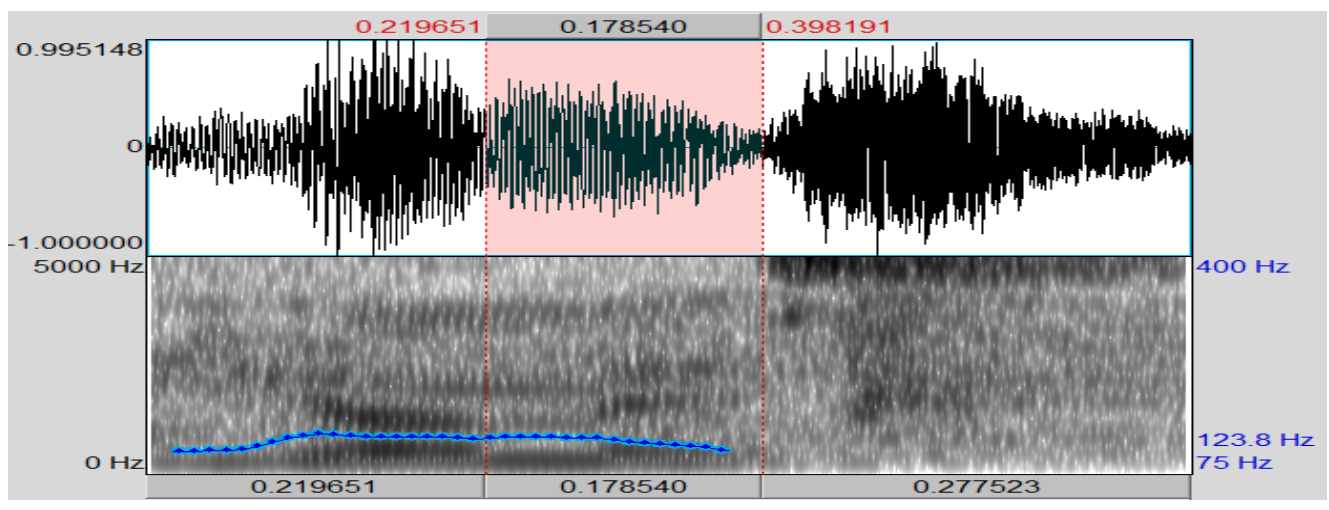

Figure 6. Respondent 10's rendition of Yomex

\subsection{Implications of Anglicization for the Yoruba Language and Culture}

One of the implications of anglicization for the Yoruba language is language endangerment. Language endangerment is a term used to portray a language that is at the verge of going into extinction. Endangerment of the Yoruba language is not without a vivid cause. It is common place knowledge that the importation of the English language into Nigeria has resulted in subtractive bilingualism especially among youths. Ogunwale and Bamigbade (2014) report that nowadays, it is only the aged that use the Yoruba language in public. This is because the English language is equated with literacy and civilisation; hence, to the detriment of their culturally rich names, the Yoruba youths anglicize their names in order to appear modern.

Findings in this study reveal that Nigerian youths seem to have a positive attitude towards English. The results show that the respondents acknowledged the fact that anglicized names are less meaningful compared to Yoruba names and they do not reflect their nationality, language and culture. Nevertheless, the respondents report that they like being addressed by their anglicized names because they feel more civilized when addressed by it. Results show further that most of the respondents seem to be ignorant of the negative implications of anglicization for the linguistic and cultural identity of the Yoruba people.

In the light of the foregoing, research hypotheses 1 and 2 in this study are confirmed while 3 and 4 are refuted: that is, (1) the anglicized names are structurally more English than Yoruba; (2) whereas meaning is central to what constitutes a name in Yoruba, the anglicized variants have no inherent meanings; (3) anglicization impacts negatively on the Yoruba language and culture; and (4) Yoruba speaking youths are more civilization-inclined, and for them, anything English is civilization that must be preserved; even to the detriment of Yoruba, their native language.

\section{Conclusion}

This study has identified the phonological processes that the selected names have undergone. It has also analysed the selected names acoustically and perceptually. The phonological processes identified in the respondents' names are substitution, epenthesis, contraction, elision, re-syllabification and stress-shift. It was observed that most of the names underwent more than one phonological process. The study revealed further that though the "new names" are structurally more English than Yoruba, they are nevertheless pronounced with Yoruba tone rather than stress by some of the respondents/bearers (cf. §. 4.2.3 \& Figure 6).

Moreover, the attitude of the respondents towards anglicization and their awareness of the implications of this phenomenon for the Yoruba language and culture are discussed. Findings revealed that most of the respondents have a positive attitude towards English and they are against the notion that anglicization of Yoruba personal names is a threat to the Yoruba language

\section{References}

Afolayan, A. (1982). Stress in Yoruba. In A. Afolayan (Ed.), Yoruba Language and Literature. Ife and Ibadan: University of Ife Press and University Press Limited. 
Ajileye, M. (2011). A Sociolinguistic Investigation of Anglicism in Personal and Business Names in the Yoruba Speech Community. An unpublished PhD dissertation, University of Ibadan.

Fajobi, E. (2013). Contextual Tonal Interaction in Spoken YNE (Yoruba Nigerian English): Evidence for Variety. Ibadan Journal of European Studies, 13, 134-172.

Faleye, J. (2014). Variant Word Stress Patterns in the Spoken English of Selected Nigerian Teachers. Covenant Journal of Language Studies (CJLS), 2(1).

Faleye, O., \& Adegoju, A. (2012). A Sociolinguistic Study of Deviant Orthographic Representation of Graduating Students' Names in a Nigerian University. Linguistik Online, 53, 11-22.

Filani, I., \& Melefa, O. M. (2014). A Socio-semiotic Study of Nicknaming among Undergraduates in a Nigerian University. Linguistik Online, 68.

Gorlach, M. (2001). A Dictionary of European Anglicisms. Oxford: Oxford University Press.

Harder, K. (2008). Names. In Microsoft Encarta 2009 [DVD]. Redmond, WA: Microsoft Corporation.

Kager, R. (1995). The Metrical Theory of Word Stress. In J. Goldsmith (Ed.), The Handbook of Phonological Theory (pp. 367-402). Cambridge: Blackwell.

Knobelauch, L. (2008). Phonological Awareness. Retrieved November, 2015, from http://www.superduperinc.com/handouts/pdf/172\%20Phonological\%20Awareness.pdf

Ogunwale, J., \& Bamigbade, O. (2014). Linguistic Alienation and Culture Subversion as Sociolinguistic Factors for Name Dropping and Change among the So-Called Yoruba Elites. Journal of Humanities and Social Science (IOSR-JHSS), 19(11), 42-53. https://doi.org/10.9790/0837-191114253

Onadipe, N. (2012). A Pragmatic Study of Selected Anglicized Abiku Names. An Unpublished B. A Long Essay. Redeemer's University, Ede, Nigeria.

Raheem, S. O. (2013). Sociolinguistic Dimension to Globalisation: Gradual Shift in Yoruba Personal Names Among Youths in Southwestern Nigeria. The African Symposium: An Online Journal of the African Educational Research Network, 13(1), 88-93.

Soneye, T. (2008). Acculturation of English into Yoruba Personal Names: A Socio-Phonetic Analysis. Journal of Social and Cultural Studies, 11(2), 1-9.

Torgesen, J., \& Mathes, P. (1998). What every Teacher should know about Phonological Awareness. Retrieved from http://www.fldoe.org/core/fileparse.php/7690/urlt/0070133-phon9872.pdf

$\begin{array}{lllll}\text { Yoruba } & \text { Vowel } & \text { Diagram. } & \text { (2018). } & \text { Retrieved }\end{array}$ https://commons.wikimedia.org/wiki/File:Yoruba_Vowel_Diagram.png

Yopp, H., \& Yopp, R. (2009). Phonological Awareness is Child's Play. Retrieved from https://www.naeyc.org/files/yc/file/200901/BTJPhonologicalAwareness.pdf

\section{Appendix A}

\section{Structural Syllabification of the Selected Original and Anglicized Yoruba names}

\begin{tabular}{|c|c|c|c|c|c|c|}
\hline $\begin{array}{l}\text { Original } \\
\text { Names }\end{array}$ & $\begin{array}{l}\text { No of } \\
\text { Syll. }\end{array}$ & Structural Syllabification & $\begin{array}{l}\text { Anglicized Version } \\
\text { of Names }\end{array}$ & $\begin{array}{l}\text { Pronunciation } \\
\text { of Names }\end{array}$ & $\begin{array}{l}\text { No of } \\
\text { Syll. }\end{array}$ & $\begin{array}{l}\text { Structural } \\
\text { Syllabification }\end{array}$ \\
\hline Àbáyòmí & 4 & $\mathrm{~V}+\mathrm{CV}+\mathrm{CV}+\mathrm{CV}$ & Yommy & [jomI $]$ & 2 & $\mathrm{CV}+\mathrm{CV}$ \\
\hline Àbáyòmí & 4 & $\mathrm{~V}+\mathrm{CV}+\mathrm{CV}+\mathrm{CV}$ & Yomex & [jomeks] & 2 & $\mathrm{CV}+\mathrm{CVCC}$ \\
\hline Abíólá & 4 & $\mathrm{~V}+\mathrm{CV}+\mathrm{V}+\mathrm{CV}$ & $\mathrm{AB}$ & [erbi:] & 2 & $\mathrm{CV}+\mathrm{CV}$ \\
\hline Abísólá & 4 & $\mathrm{~V}+\mathrm{CV}+\mathrm{CV}+\mathrm{CV}$ & Abby & {$[æ b \mathrm{bl}]$} & 2 & $\mathrm{~V}+\mathrm{CV}$ \\
\hline Adédàmólá & 5 & $\mathrm{~V}+\mathrm{CV}+\mathrm{CV}+\mathrm{CV}+\mathrm{CV}$ & Deydah & {$[\operatorname{deI} x]$} & 2 & $\mathrm{CV}+\mathrm{CV}$ \\
\hline Adésólá & 4 & $\mathrm{~V}+\mathrm{CV}+\mathrm{CV}+\mathrm{CV}$ & Dessy & {$[\mathrm{des} I]$} & 2 & $\mathrm{CV}+\mathrm{CV}$ \\
\hline Ayòmípòsi & 5 & $\mathrm{~V}+\mathrm{CV}+\mathrm{CV}+\mathrm{CV}+\mathrm{CV}$ & $\mathrm{AY}$ & [erwar] & 2 & $\mathrm{~V}+\mathrm{CV}$ \\
\hline Bólájí & 3 & $\mathrm{CV}+\mathrm{CV}+\mathrm{CV}$ & Beejay & [bi:dzer] & 2 & $\mathrm{CV}+\mathrm{CV}$ \\
\hline Bólúwatifé & 5 & $\mathrm{CV}+\mathrm{CV}+\mathrm{CV}+\mathrm{CV}+\mathrm{CV}$ & Bolex & [bəuleks] & 2 & $\mathrm{CV}+\mathrm{CVCC}$ \\
\hline Bùsáyò & 3 & $\mathrm{CV}+\mathrm{CV}+\mathrm{CV}$ & Bussy & [busi] & 2 & $\mathrm{CV}+\mathrm{CV}$ \\
\hline Dámilólá & 4 & $\mathrm{CV}+\mathrm{CV}+\mathrm{CV}+\mathrm{CV}$ & Dammy & [dæmI $]$ & 2 & $\mathrm{CV}+\mathrm{CV}$ \\
\hline Dèjì & 2 & $\mathrm{CV}+\mathrm{CV}$ & Deiji & [derdzI] & 2 & $\mathrm{CV}+\mathrm{CV}$ \\
\hline Dọlápò & 3 & $\mathrm{CV}+\mathrm{CV}+\mathrm{CV}$ & Dollypee & [dDlıpi:] & 3 & $\mathrm{CV}+\mathrm{CV}+\mathrm{CV}$ \\
\hline Fémi & 2 & $\mathrm{CV}+\mathrm{CV}$ & FM & [efem] & 2 & $\mathrm{VC}+\mathrm{VC}$ \\
\hline Fikémi & 3 & $\mathrm{CV}+\mathrm{CV}+\mathrm{CV}$ & Fiks & [fiks] & 1 & CVCC \\
\hline
\end{tabular}




\begin{tabular}{|c|c|c|c|c|c|c|}
\hline Foláké & 3 & $\mathrm{CV}+\mathrm{CV}+\mathrm{CV}$ & Flaky & [flerki] & 2 & $\mathrm{CCV}+\mathrm{CV}$ \\
\hline Folúsó & 3 & $\mathrm{CV}+\mathrm{CV}+\mathrm{CV}$ & Folly & [fDli $]$ & 2 & $\mathrm{CV}+\mathrm{CV}$ \\
\hline İtùnú & 3 & $\mathrm{~V}+\mathrm{CV}+\mathrm{CV}$ & Itee & [arti:] & 2 & $\mathrm{~V}+\mathrm{CV}$ \\
\hline İtùnú & 3 & $\mathrm{~V}+\mathrm{CV}+\mathrm{CV}$ & Itunez & [artju:nz] & 2 & $\mathrm{~V}+\mathrm{CCVCC}$ \\
\hline Jùmòké & 3 & $\mathrm{CV}+\mathrm{CV}+\mathrm{CV}$ & Jummy & [ḑumi] & 2 & $\mathrm{CV}+\mathrm{CV}$ \\
\hline Káyòdé & 3 & $\mathrm{CV}+\mathrm{CV}+\mathrm{CV}$ & Kay & [keI] & 1 & $\mathrm{CV}$ \\
\hline Kéhìndé & 3 & $\mathrm{CV}+\mathrm{CV}+\mathrm{CV}$ & Kenny & [kenI] & 2 & $\mathrm{CV}+\mathrm{CV}$ \\
\hline Lọlá & 2 & $\mathrm{CV}+\mathrm{CV}$ & Lohlar & [ləulæ] & 2 & $\mathrm{CV}+\mathrm{CV}$ \\
\hline Lọlá & 2 & $\mathrm{CV}+\mathrm{CV}$ & Lolly & {$\left[\mathrm{lDl}_{\mathrm{I}}\right]$} & 2 & $\mathrm{CV}+\mathrm{CV}$ \\
\hline Máyòwá & 3 & $\mathrm{CV}+\mathrm{CV}+\mathrm{CV}$ & Mayor & [meijD] & 2 & $\mathrm{CV}+\mathrm{CV}$ \\
\hline Moyòadé & 4 & $\mathrm{CV}+\mathrm{CV}+\mathrm{V}+\mathrm{CV}$ & Moh & [məu] & 1 & $\mathrm{CV}$ \\
\hline Níke & 2 & $\mathrm{CV}+\mathrm{CV}$ & Nikky & [nIkI] & 2 & $\mathrm{CV}+\mathrm{CV}$ \\
\hline Olaitan & 4 & $\mathrm{~V}+\mathrm{CV}+\mathrm{V}+\mathrm{CV}$ & Lhait & [lart] & 1 & $\mathrm{CVC}$ \\
\hline Olúmìdé & 4 & $\mathrm{~V}+\mathrm{CV}+\mathrm{CV}+\mathrm{CV}$ & Olumy & [oulumi] & 3 & $\mathrm{~V}+\mathrm{CV}+\mathrm{CV}$ \\
\hline Opéyẹmí & 4 & $\mathrm{~V}+\mathrm{CV}+\mathrm{CV}+\mathrm{CV}$ & Opzy & [DpzI] & 2 & $\mathrm{VC}+\mathrm{CV}$ \\
\hline Opéyẹmí & 4 & $\mathrm{~V}+\mathrm{CV}+\mathrm{CV}+\mathrm{CV}$ & Oppey & [Dpi:] & 2 & $\mathrm{~V}+\mathrm{CV}$ \\
\hline Ségun & 2 & $\mathrm{CV}+\mathrm{CV}$ & Shegz & [ eggz] & 1 & CVCC \\
\hline Sèsan & 2 & $\mathrm{CV}+\mathrm{CV}$ & Shessy & {$[$ JesI $]$} & 2 & $\mathrm{CV}+\mathrm{CV}$ \\
\hline Sojí & 2 & $\mathrm{CV}+\mathrm{CV}$ & SOJ & [esəudzer] & 3 & $\mathrm{VC}+\mathrm{V}+\mathrm{CV}$ \\
\hline Sùbòmí & 3 & $\mathrm{CV}+\mathrm{CV}+\mathrm{CV}$ & Shubby & [ [ubi $]$ & 2 & $\mathrm{CV}+\mathrm{CV}$ \\
\hline Súnkànmí & 3 & $\mathrm{CV}+\mathrm{CV}+\mathrm{CV}$ & Sunky & [sunkI] & 2 & $\mathrm{CVC}+\mathrm{CV}$ \\
\hline Táíwò & 2 & $\mathrm{CV}+\mathrm{V}+\mathrm{CV}$ & Tee & [ti:] & 1 & $\mathrm{CV}$ \\
\hline Táyò & 2 & $\mathrm{CV}+\mathrm{CV}$ & Tee-Y & [ti:war] & 2 & $\mathrm{CV}+\mathrm{CV}$ \\
\hline Tèmídayò & 4 & $\mathrm{CV}+\mathrm{CV}+\mathrm{CV}+\mathrm{CV}$ & TemmyD & [termıdi:] & 3 & $\mathrm{CV}+\mathrm{CV}+\mathrm{CV}$ \\
\hline Tèmítáyò & 4 & $\mathrm{CV}+\mathrm{CV}+\mathrm{CV}+\mathrm{CV}$ & Temmy & [termI $]$ & 2 & $\mathrm{CV}+\mathrm{CV}$ \\
\hline Tèmítópé & 4 & $\mathrm{CV}+\mathrm{CV}+\mathrm{CV}+\mathrm{CV}$ & Topsy & [tDpsI] & 2 & $\mathrm{CVC}+\mathrm{CV}$ \\
\hline Téníolá & 4 & $\mathrm{CV}+\mathrm{CV}+\mathrm{V}+\mathrm{CV}$ & Tenny & [tenI $]$ & 2 & $\mathrm{CV}+\mathrm{CV}$ \\
\hline Tósìn & 2 & $\mathrm{CV}+\mathrm{CV}$ & Tosign & [təusain] & 2 & $\mathrm{CV}+\mathrm{CVC}$ \\
\hline Tóyìn & 2 & $\mathrm{CV}+\mathrm{CV}$ & Toy & {$[\mathrm{toI}]$} & 1 & $\mathrm{CV}$ \\
\hline Tijésùnimí & 5 & $\mathrm{CV}+\mathrm{CV}+\mathrm{CV}+\mathrm{CV}+\mathrm{CV}$ & Teejay & [ti:dzer] & 2 & $\mathrm{CV}+\mathrm{CV}$ \\
\hline Tìmíléhìn & 4 & $\mathrm{CV}+\mathrm{CV}+\mathrm{CV}+\mathrm{CV}$ & Timmy & [trmI] & 2 & $\mathrm{CV}+\mathrm{CV}$ \\
\hline Tóyòsí & 3 & $\mathrm{CV}+\mathrm{CV}+\mathrm{CV}$ & Toyos & [təujDs] & 2 & $\mathrm{CV}+\mathrm{CVC}$ \\
\hline Túnjí & 2 & $\mathrm{CV}+\mathrm{CV}$ & Teejay & [ti:d3eI] & 2 & $\mathrm{CV}+\mathrm{CV}$ \\
\hline Wálé & 2 & $\mathrm{CV}+\mathrm{CV}$ & Whalex & [werleks] & 2 & $\mathrm{CV}+\mathrm{CVCC}$ \\
\hline Wọlé & 2 & $\mathrm{CV}+\mathrm{CV}$ & Wolex & [woleks] & 2 & $\mathrm{CV}+\mathrm{CVCC}$ \\
\hline
\end{tabular}

\section{Appendix B}

Substitution and Contraction of Sounds and Syllables Between the Informants' Original and Anglicized Names

\begin{tabular}{|c|c|c|c|c|c|c|}
\hline $\mathrm{S} / \mathrm{N}$ of items & Original Names & Transcript-ion & No of Syllables & Anglicized Names & Transcript-ion & No of Syllables \\
\hline 1 & Abíólá & [abiola] & 4 & $\mathrm{AB}$ & [erbi:] & 2 \\
\hline 2 & Adésólá & [adesola] & 4 & Dessy & [desi] & 2 \\
\hline 3 & Ayòmípòsi & [ajomiposi] & 5 & AY & [erwaI] & 2 \\
\hline 4 & Bólájí & [bolaji] & 3 & Beejay & [bi:dzeI] & 2 \\
\hline 5 & Bùsáyò & [busajo] & 3 & Bussy & [busi] & 2 \\
\hline 6 & Fikémi & [fikemi] & 3 & Fiks & [fiks] & 1 \\
\hline 7 & Folúsó & [folufo] & 3 & Folly & {$[\mathrm{fDl} I]$} & 2 \\
\hline 8 & Ìtùnú & [itunu] & 3 & Itunez & [artju:nz] & 2 \\
\hline 9 & Ìtùnú & [itunu] & 3 & Itee & [arti:] & 2 \\
\hline 10 & Jùmòké & [fumoke] & 3 & Jummy & [dzumi] & 2 \\
\hline 11 & Káyòdé & [kajode] & 3 & Kay & {$[\mathrm{keI}]$} & 1 \\
\hline 12 & Kéhìndé & [kehĩde] & 3 & Kenny & [kenI] & 2 \\
\hline 13 & Máyòwá & [majowa] & 3 & Mayor & [merjo] & 2 \\
\hline 14 & Opéyẹmí & [эpєjєmi] & 4 & Opzy & [DpzI] & 2 \\
\hline 15 & Opéyẹmí & [opejemi] & 4 & Oppey & [opi:] & 2 \\
\hline 16 & Ségun & {$\left[\int \varepsilon g \tilde{u}\right]$} & 2 & Shegz & {$\left[\int \mathrm{egz}\right]$} & 1 \\
\hline 17 & Sùbòmí & [ Jubomi] & 3 & Shubby & {$[$ Jubi $]$} & 2 \\
\hline 18 & Súnkànmí & [sũkãmi] & 3 & Sunky & [sunkI] & 2 \\
\hline 19 & Táíwò & [taiwo] & 3 & Tee & [ti:] & 1 \\
\hline 20 & Tèmídayò & [temidajo] & 4 & TemmyD & [termidi:] & 3 \\
\hline 21 & Tóyìn & [tojĩ $]$ & 2 & Toy & {$[\mathrm{t} J \mathrm{I}]$} & 1 \\
\hline 22 & Tijésùnimí & [tijesunimi] & 5 & Teejay & [ti:dzer] & 2 \\
\hline
\end{tabular}




\section{Copyrights}

Copyright for this article is retained by the author(s), with first publication rights granted to the journal.

This is an open-access article distributed under the terms and conditions of the Creative Commons Attribution license (http://creativecommons.org/licenses/by/4.0/). 